\title{
Helicobacter pylori 23S rRNA gene A2142G, A2143G, T2182C, and C2195T mutations associated with clarithromycin resistance detected in Sudanese patients
}

Aalaa Mahgoub Albasha ${ }^{1 *}$, Maram M. Elnosh¹, Esraa Hassan Osman¹, Duha M. Zeinalabdin', Amira A. M. Fadl², Musa Abdalla Ali ${ }^{3}$ and Hisham N. Altayb $b^{1,4}$

\begin{abstract}
Background: Clarithromycin resistant Helicobacter pylori (H. pylori) strains represent a worldwide health problem. These stains are usually carrying mutations within the $23 \mathrm{~S}$ rRNA gene associated with clarithromycin resistance. This study aimed to detect $\mathrm{H}$. pylori and clarithromycin resistant associated mutations from Sudanese patients with gastritis symptoms.

Materials and methods: Two hundred and eighty-eight gastric biopsies were collected using gastrointestinal endoscopy from patients with gastritis symptoms in different hospitals in Khartoum state. H. pylori was detected by PCR using primer targeting 16S rRNA. Then allele-specific PCR and DNA sequencing were used to screen for the presence of A2142G and A2143G point mutations.

Results: Out of 288 samples, H. pylori was detected in $88(\sim 30.6 \%)$ samples by $16 \mathrm{~s}$ RNA. Allele-specific PCR detected the variant A2142G in 9/53 ( 17\%) sample, while A2143G mutation was not found in any sample. The DNA sequencing revealed the presence of mutations associated with clarithromycin-resistance in $36 \%(9 / 25)$ of samples; the A2142G was present in one sample, A2143G in 5 samples and T2182C in 4 samples. Additionally, another point mutation (C2195T) was detected in 3 samples. There was no association of $23 S$ rRNA gene point mutations with gender, age group, and patients' geographical distribution.

Conclusion: This study revealed a high frequency (36\%) of mutations associated with clarithromycin resistance using DNA sequencing of the $23 \mathrm{~S}$ rRNA gene's $V$ domain. This information should be taken into consideration to avoid eradication therapy failing.
\end{abstract}

Keywords: H. pylori, Clarithromycin-resistance, A2142G, A2143G, Sudan

\footnotetext{
* Correspondence: loleta95227@outlook.com

${ }^{1}$ Department of Microbiology, College of Medical Laboratory Sciences, Sudan University for Science and Technology, Khartoum, Sudan

Full list of author information is available at the end of the article
}

\section{$\triangle B M C$}

(c) The Author(s). 2021 Open Access This article is licensed under a Creative Commons Attribution 4.0 International License, which permits use, sharing, adaptation, distribution and reproduction in any medium or format, as long as you give appropriate credit to the original author(s) and the source, provide a link to the Creative Commons licence, and indicate if changes were made. The images or other third party material in this article are included in the article's Creative Commons licence, unless indicated otherwise in a credit line to the material. If material is not included in the article's Creative Commons licence and your intended use is not permitted by statutory regulation or exceeds the permitted use, you will need to obtain permission directly from the copyright holder. To view a copy of this licence, visit http://creativecommons.org/licenses/by/4.0/ The Creative Commons Public Domain Dedication waiver (http://creativecommons.org/publicdomain/zero/1.0/) applies to the data made available in this article, unless otherwise stated in a credit line to the data. 


\section{Introduction}

Helicobacter pylori (H. pylori) is an exceptional bacterium in its ability to create permanent stomach colonization in untreated humans. Multiple factors contribute to the characteristic gut colonization, inflammation, alteration in the production of gastric acid, and tissue destruction caused by $H$. pylori [1]. The mechanisms by which $H$. pylori causes mucosal inflammation and damage are not well described but have both bacterial and host factors likely to be involved. Toxins and lipopolysaccharides produced by bacteria can damage the mucosal cells, and the ammonia released by the action of urease can also directly harm the cells [2]. In many developing countries, the infection rate has been reported to be as high as $70-80 \%$ [3]. H. pylori is responsible for more than $80 \%$ of peptic ulcer diseases, and $95 \%$ or more of duodenal ulcers [4]. Diagnostic testing is typically divided into invasive (endoscopic) and noninvasive approaches. The invasive diagnostic method involves endoscopic imaging, histology, rapid urease examination, culture, and molecular techniques. Non-invasive diagnostic tests include breathing tests for urea, antigen check for stools, and serological tests [5].

Elimination of $H$. pylori is based on successful treatment with a proton pump inhibitor (PPI), such as omeprazole, lansoprazole, and rabeprazole, and at least two antibiotics of clarithromycin (CLR), metronidazole (MTZ), amoxicillin (AMX), and tetracycline (TET). Combination therapy consisting of a PPI, CLR, and either AMX or MTZ for up to 14 days is one of the common approved first-line regimens [6]. As opposed to other macrolides, clarithromycin is used as an antibiotic against $H$. pylori due to its unusual acid stability. The antibiotic reversibly binds to domain II hairpin 35 and the domain $\mathrm{V}$ peptidyl transferase loop of the $23 \mathrm{~s}$ rRNA molecule inside the ribosomal subunit of the 50s. This binding prevents protein elongation by releasing peptidyl-tRNA prematurely from the acceptor site and thus effectively blocks the synthesis of bacterial proteins [7]. One mechanism by which $H$. pylori acquires antibiotic resistance is through vertical mutation transmission [8]. Clarithromycin-resistant strains also carry mutations within the gene $23 \mathrm{~S}$ rRNA. Several studies have shown that $\mathrm{A} / \mathrm{G}$ point mutations in Domain $\mathrm{V}$ at positions 2142 and 2143 or a $\mathrm{T} / \mathrm{C}$ mutation in Domain VI of the 23S rRNA gene cause clarithromycin resistance [9-11]. The prevalence of antibiotic-resistant H. pylori is increasing worldwide [12]. Antibiotics resistance is the main factor of failure of $H$. pylori eradication therapies [13]. Clarithromycin resistance, in particular, has a major negative impact on the efficacy of the recommended first-line triple therapy of $H$. pylori [14]. In Sudan, there is very limited data on the prevalence of clarithromycinresistant $H$. pylori. The aim of this study was to determine the $H$. pylori resistance to clarithromycin in Sudanese patients with gastritis symptoms.

\section{Materials and methods Collection of biopsy specimens}

Gastric biopsies were collected from 288 patients, in which both the antrum and corpus had been sampled by endoscopy. Biopsies were collected by physicians from patients indicated for gastric endoscopy at different hospitals in Khartoum State (Omdurman Medical Military Hospital, Al-Amal National Hospital, Police Hospital, Ibn Sina Hospital, and Fedail hospital) at the period from June/2018 to January/2019.

\section{Preservation and processing of specimens}

The specimens were immediately placed in thioglycollate broth, which provides anaerobic conditions until processing [15]. Manual grinding of biopsies took place using disposable material [16].

\section{Bacterial identification}

The DNA of Helicobacter pylori has been extracted from specimens of the gastric biopsies using the guanidine chloride method [17]. Biopsies were ground by sterile blades and tips and then washed twice by phosphate buffer saline (PBS) to eliminate excess media. We add to the pellet $2 \mathrm{ml}$ of lysis buffer, $10 \mu \mathrm{l}$ of proteinase $\mathrm{K}, 1 \mathrm{ml}$ of guanidine chloride, and $300 \mu \mathrm{l}$ of ammonium (NH4) acetate, vortexed and incubated at $65^{\circ} \mathrm{C}$ for $2 \mathrm{~h}$. The mixture was cooled to ambient temperature, and then 2 $\mathrm{ml}$ of pre-cooled chloroform was applied, vortexed, and centrifuged for $5 \mathrm{~min}$ at $3000 \mathrm{rpm}$. The upper layer of the mixture was moved to a new tube, and $10 \mathrm{ml}$ of absolute cold ethanol was applied, shaken, and held for $2 \mathrm{~h}$ or overnight at $-20^{\circ} \mathrm{C}$. The tube was then centrifuged for $15-20 \mathrm{~min}$ at $3000 \mathrm{rpm}$, the supernatant was carefully removed, and the tube was inverted for $5 \mathrm{~min}$ on a tissue paper. The pellet was washed with $70 \%$ ethanol 4 $\mathrm{ml}$, centrifuged for $5 \mathrm{~min}$ at $3000 \mathrm{rpm}$. The supernatant was poured away, allowing the pellet to dry for $10 \mathrm{~min}$. Then re-suspended into $50 \mu \mathrm{l}$ of distilled water, briefly vortexed, and held overnight at $-20^{\circ} \mathrm{C}$. The extracted DNA was stored at $-70{ }^{\circ} \mathrm{C}$ until use.

\section{Polymerase chain reaction (PCR)}

Two primer sets were used for the detection of the bacteria, targeting $16 \mathrm{~S}$ rRNA (532 bp) [18],). Allele-specific PCR was used for the detection of A2142G and A2143G point mutations using four primers called FP-1, RP-1, RP2142G, and FP2143G (Table 1). When the strain is wild type (wt), neither RP2142G nor FP2143G anneals with the template and polymerase chain reaction (PCR) amplification proceeds between FP-1 and RP-1, resulting in a $320 \mathrm{bp}$ amplicon. In the case of the presence of 
Table 1 Primers sequences and PCR protocols used in this study

\begin{tabular}{lllll}
\hline Protocols & Primer name & Primer sequence (5'-3') & Amplicon size (bp & References \\
\hline 1st & 16s RNA & GCTAA GAGA TCA GCC TAT GTCC & 532 & \\
2nd & TGGCAATCAGCGTCAGGTATG & & \\
& FP-1 & TCGAAGGTTAAGAGGATGCGTCAGTC & 320 & \\
& RP-1 & GACTCCATAAGAGCCAAAGCCCTAC & & \\
& RP2142G & AGTAAAGGTCCACGGGGTATTCC & 238 \\
& FP2143G & CCGCGGCAAGACAGAGA & 118 \\
\hline
\end{tabular}

A2142G mutation, the PCR amplification primarily takes place between FP-1 and RP2142 G, which results in an amplicon of $238 \mathrm{bp}$. Similarly, in the case of the A2143G mutation, the PCR amplification goes between FP2143G and RP-1, resulting in an amplicon of $118 \mathrm{bp}$ [19]. The primers were dissolved according to manufacturer guidelines to prepare $10 \mathrm{pmol} / \mu \mathrm{l}$.

The first protocol used for amplification of $16 \mathrm{~S}$ rRNA was as follows: initial activation at $94^{\circ} \mathrm{C}$ for $3 \mathrm{~min}$, followed by 35 cycles at $94{ }^{\circ} \mathrm{C}$ for $30 \mathrm{~s}, 53^{\circ} \mathrm{C}$ for 30 s, and $72{ }^{\circ} \mathrm{C}$ for $45 \mathrm{~s}$, and a final extension at $72{ }^{\circ} \mathrm{C}$ for $5 \mathrm{~min}$ (Table 1) [18].

The second protocol used for amplification of Allele-specific was as follows: initial denaturation at $95^{\circ} \mathrm{C}$ for $5 \mathrm{~min}$ followed by 35 cycles of denaturation at $95^{\circ} \mathrm{C}$ for $15 \mathrm{~s}$, annealing at $60.5^{\circ} \mathrm{C}$ for $20 \mathrm{~s}$, and extension at $68^{\circ} \mathrm{C}$ for the 30s and a final extension of $2 \mathrm{~min}$ at $68^{\circ} \mathrm{C}$ (Table 1) [19].

\section{DNA sequencing}

A total of 25 PCR amplified products were sent for sequencing (by BGI, business, China) for both strands of PCR products. The pairwise alignment was done for successful sequences by BLAST, and then multiple sequence alignment was done by BioEdit software [20]. The sequences were compared with the $23 \mathrm{~S}$ rRNA reference (U27270) and submitted to GenBank with accession numbers found in the additional files.

\section{Statistical analysis}

The obtained data were analyzed using IBM SPSS statistics 20. The chi-square test was used to compare the correlations and associations between variables ( $p$-value $\leq 0.05$ considered significant).

\section{Results}

\section{Demographic data}

One hundred and twenty-eight (44.4\%) were females, and one hundred sixty (55.6\%) were males from two hundred and eighty-eight enrolled patients. They were divided into two age groups: adolescents (10) and adults (276). One hundred seventy-five (60.8\%) specimens were collected from Khartoum city, and one hundred and thirteen (39.2\%) specimens were collected from Omdurman city.

\section{Endoscopic findings}

According to endoscopic findings by a physician, one hundred and ninety (66\%) patients were diagnosed as gastritis, twenty-nine (10\%) as a gastric ulcer (G. ulcer), twenty-five (9\%) as a duodenal ulcer (D. ulcer), fifteen (5\%) as esophagitis and twenty-nine (10\%) were of normal finding.

\section{Detection of $\mathrm{H}$. pylori}

Out of 288 specimens investigated for the presence of $H$. pylori using primer targeting $16 \mathrm{~S}$ rRNA by PCR, $H$. pylori were positive in $88 / 288(\sim 30.6 \%)$ specimens. Wild type (wt) $23 \mathrm{~S}$ rRNA was detected in 62(21.5\%) specimens, and both $16 \mathrm{~s}$ and wt $23 \mathrm{~s}$ RNA were positive together in 53(18.4\%) specimens (Fig. 1).

Association between the presence of $H$. pylori with the epidemiological and endoscopic findings

There was no significant correlation between the presence of $H$. pylori, epidemiological findings (Gender, age group, and geographical distribution of patients), and endoscopic findings in this study.

\section{Detection of A2142G and A2143G point mutations by allele-specific PCR}

The A2142G point mutation was detected in 9/53 ( $17 \%$ ) specimens, whereas the second mutation (A2143G) was not detected in all samples.

\section{DNA sequencing results}

From twenty-five successfully sequenced samples, 12 samples exhibited different types of mutations at $23 \mathrm{~S}$ rRNA gene, 9 (36\%) samples showed mutations associated with clarithromycin resistance. And three samples reported with a mutation (C2195T) have no association with clarithromycin resistance. From the mutation associated with clarithromycin resistance, one sample showed the presence of $\mathrm{A} 2142 \mathrm{G}$ point mutation, and the A2143G was found in 5 samples. Two other mutations (T2182C and C2195T) were detected in 4 and 3 samples, respectively. The $\mathrm{A} 2142 \mathrm{G}$ was detected in one sample 


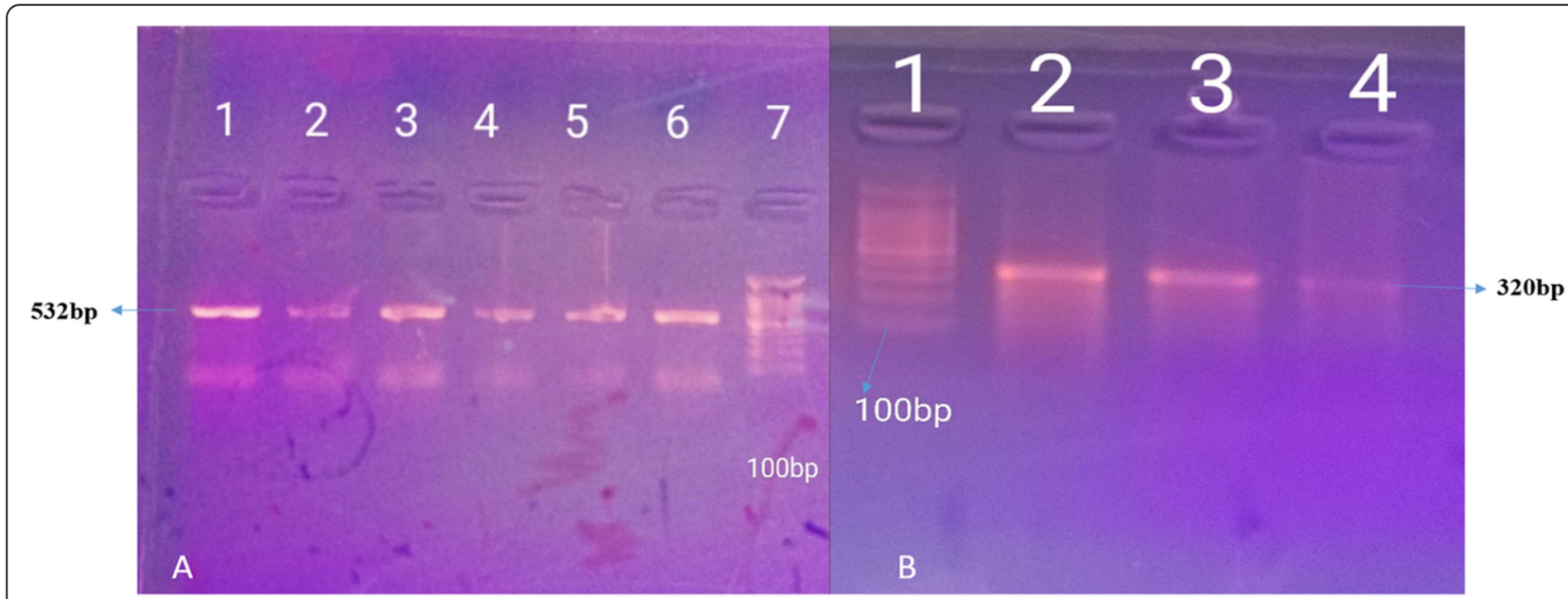

Fig. 1 a PCR amplification of $\mathrm{H}$. pylori detection genes $16 \mathrm{~S}$ RNA in addition to wild type $23 \mathrm{~S}$ rRNA on 1.5\% agarose gel electrophoresis. A: Lane 7 marker (100-1500 bp), lanes 1 to 6 contain amplicons of 16 s RNA (532 bp). b. Lane 1 marker (100-1500 bp). Lanes 2, 3, and 4 include amplicons of wt 23 s RNA (320 bp)

labeled D20, A2143G mutation detected in 5 samples D19, D33, K2, K37, and M14, T2182C mutation was detected in samples F11, K37, M11, and C5. The C2195T was detected in 3 samples D3, D4, and D34 (Fig. 2).

\section{Discussion}

H. pylori infection is increasingly reported nowadays. Although patients are receiving treatment, the problem of antibiotic resistance still hinders their recovery. In particular, clarithromycin is the most prescribed antibiotic by physicians, and resistance to it may lead to treatment failure [21].

In this study, out of 288 patients with gastric pain, $66 \%$ were diagnosed as gastritis, $10 \%$ as gastric ulcer, $9 \%$ as duodenal ulcer, $5 \%$ as esophagitis, and $10 \%$ were normal patients. This finding agrees with other studies [22, 23 , which found that gastritis is the most prevalent gastric disease.
Although culture isolation has been the standard method for the detection of the organism, but it may not be the most appropriate method for detection of $H$. pylori like organism due to cost, the special conditions required for specimen transport and growth, and the long interval between specimen harvest and test results, which delay treatment decision [15]. According to Malfertheiner [24] molecular technologies should be implemented as alternatives to traditional $H$. pylori Identification. In this study, the prevalence of $H$. pylori infection was $30.6 \%$ (88/288), using PCR targeting both 16S RNA genes. The latest prevalence rates of $H$. pylori among gastric biopsies from Sudanese patients were $21.1 \%$ using PCR targeting $16 \mathrm{~S}$ rRNA gene [25], and $22.2 \%$ using culture [26]. This variation could be attributed to that in our study, PCR was directly done from specimens without culturing step, which may minimise detection chance due to difficulties of cultivation.

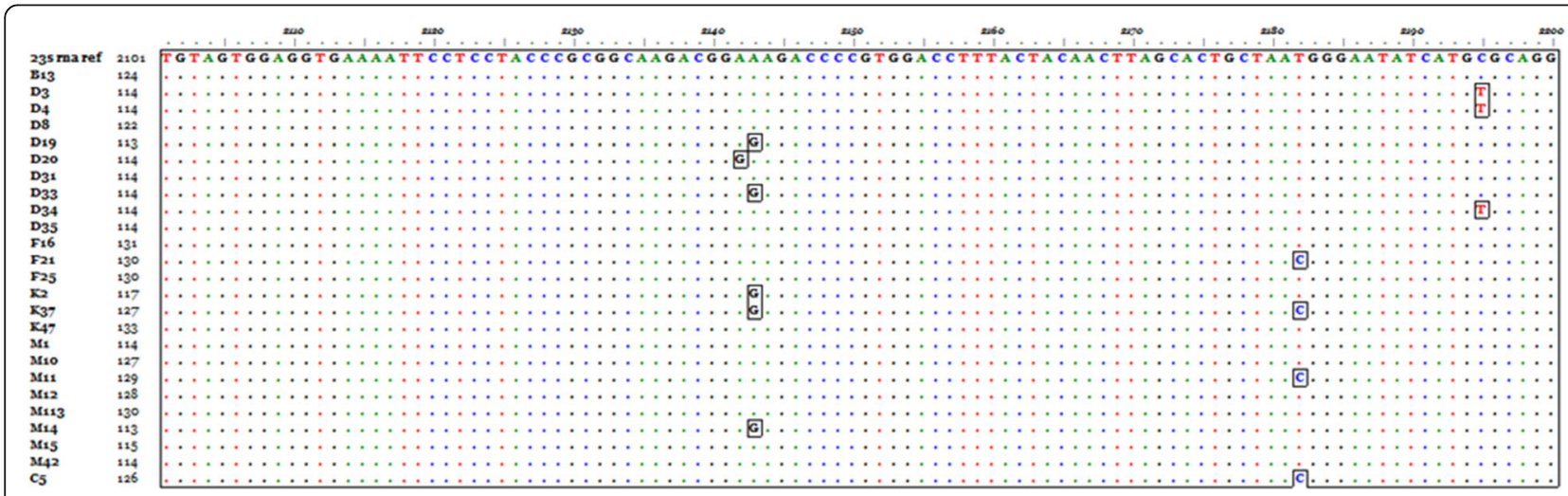

Fig. 2 Multiple sequence alignment of 235 rRNA gene sequences compared to a reference gene, the mutant nucleotides appear in boxes 
H. pylori resist clarithromycin by specific mutations in the peptidyl transferase loop of the 23S rRNA molecule's $\mathrm{V}$ domain [27-29]. Worldwide, the prevalence of clarithromycin-resistant strains of H. pylori is $19.4 \%$ [30]. Generally, countries with an antibiotic resistance rate of more than $20 \%$ alter their treatment strategies [31]. Our study revealed a higher frequency (36\%) of mutations associated with clarithromycin resistance using DNA sequencing of $\mathrm{V}$ domain of $23 \mathrm{~S}$ rRNA gene. While using the allele-specific PCR, the frequency of mutations associated with clarithromycin resistance in our specimens was $17 \%$ (9/53). These variations could be due to the low sensitivity of allele-specific PCR compared to DNA sequencing [32]. Also, in this study, allele-specific PCR targeted only two common mutations (A2142G and A2143G), while sequencing revealed all SNPs in the amplified region.

The point mutation A2142G was detected in 17\% (9/53) of specimens using allele-specific PCR. This percentage is a noticeable amount compared with Tran [33] study in Vietnam, which found this mutation in about $3.6 \%$, variation in the population may represent a critical factor.

Like Ghaith's [23] study, point mutation A2143G was fallen to be detected by PCR although different PCR protocols were tried; this could be justified according to Cheng [34], which is that there is only one nucleotide difference between wild-type DNA and point mutation in DNA sequence. Therefore, the unusual mutations between large excess wild-type alleles are difficult to detect by traditional gene variation assays. In contrast, both mutations A2142G and A2143G appeared by DNA sequencing technique, and they are already known to cause reduced affinity of the ribosome for CLA [11].

As it appeared in our results, differences in detection methods has a larger impact. Fallen in the detection of A2143G mutiation by PCR and its appearance by DNA sequencing techniques may suggest that the percentage of clarithromycin resistance gene mutation may be more than the above results.

DNA sequencing also showed the presence of T2182C mutation in some specimens. According to Jung [35] suggestion, this mutation is nonspecific. In contrast, Khan [36] confirmed that this mutation is associated with clarithromycin. Besides, point mutation C2195T was detected by sequencing, and according to Fasciana [37], it has no relation with clarithromycin resistance.

\section{Abbreviations}

AMX: Amoxicillin; Bp: Base Pair; CLR: Clarithromycin; DNA: Deoxyribo-Nucleic Acid; MTZ: Metronidazole; PCR: Polymerase Chain Reaction; PPI: Proton Pump Inhibitor; rRNA: Ribosomal Ribonucleic acid; SPSS: Statistical package for social science; TET: Tetracycline

\section{Acknowledgments}

Not applicable.

\section{Authors' contributions}

HNA, AMA, MMA, and EHO designed the study, HNA, AMA, MMA, EHO, DMZ, performed the experiments, analyzed the data, AAM collected gastric biopsies and performed clinical diagnosis, wrote the manuscript, HNA and MAA supervised the study and revised manuscript critically, all the authors read and approved the final version of the manuscript.

Funding

This study was funded by TWAS research grant No: 17-516 RG/BIO/AF/ AC_G-FR3240297732.

\section{Availability of data and materials}

The datasets used and analyzed during the current study, in addition to accession numbers of GenBank submitted sequences are available at https:// doi.org/10.6084/m9.figshare.13160144.v2

Ethics approval and consent to participate

The research was approved by the Khartoum state Ministry of health research department on 1/3/2018.

All methods were carried out in accordance with relevant guidelines and regulations. Informed consent was obtained from all adult patients and parents of the adolescent

Consent for publication

Not applicable.

\section{Competing interests}

The authors declare that they have no competing interests.

\section{Author details}

'Department of Microbiology, College of Medical Laboratory Sciences, Sudan University for Science and Technology, Khartoum, Sudan. ${ }^{2}$ Department of Medicine, The National Ribat University, Ribat University Hospital, Khartoum, Sudan. ${ }^{3}$ Department of Microbiology, faculty of Medical Laboratory Science, University of Khartoum, Khartoum, Sudan. ${ }^{4}$ Department of Biochemistry,

Faculty of Sciences, King Abdulaziz University, Jeddah 21452, Saudi Arabia.

Received: 17 October 2020 Accepted: 13 January 2021

Published online: 03 February 2021

\section{References}

1. Murray PR, Rosenthal KS, Pfaller MA. Medical microbiology: Elsevier health sciences; 2015.

2. Carroll KC, Hobden JA, Miller S, Morse S, Mietzner T, Detrick B, Mitchell TG, McKerrow JH, Sakanari JA. Microbiología médica: McGraw-Hill Interamericana; 2016.

3. Hu B, Zhao F, Wang S, Olszewski MA, Bian H, Wu Y, Kong M, Xu L, Miao Y, Fang $Y$. A high-throughput multiplex genetic detection system for Helicobacter pylori identification, virulence and resistance analysis. Future Microbiol. 2016;11(10):1261-78

4. Dong SX, Chang CC, Rowe KJ. A collection of the etiological theories, characteristics, and observations/phenomena of peptic ulcers in existing data. Data Brief. 2018;19:1058-67.

5. Wang Y-K, Kuo F-C, Liu C-J, Wu M-C, Shih H-Y, Wang SS, Wu J-Y, Kuo C-H, Huang Y-K, Wu D-C. Diagnosis of Helicobacter pylori infection: current options and developments. World J Gastroenterol: WJG. 2015;21(40):11221.

6. Rasheed F, Campbell BJ, Alfizah H, Varro A, Zahra R, Yamaoka Y, Pritchard DM. Analysis of clinical isolates of Helicobacter pylori in Pakistan reveals high degrees of pathogenicity and high frequencies of antibiotic resistance. Helicobacter. 2014;19(5):387-99.

7. Arslan N, Yılmaz Ö, Demiray-Gürbüz E. Importance of antimicrobial susceptibility testing for the management of eradication in Helicobacter pylori infection. World J Gastroenterol. 2017;23(16):2854.

8. Eng NF, Ybazeta G, Chapman K, Fraleigh NL, Letto R, Altman E, Diaz-Mitoma F. Antimicrobial susceptibility of Canadian isolates of Helicobacter pylori in northeastern Ontario. Can J Infect Dis Med Microbiol. 2015;26(3):137-44.

9. Kim JM, Kim J-S, Kim N, Kim Y-J, Kim IY, Chee YJ, Lee C-H, Jung HC. Gene mutations of $23 \mathrm{~S}$ rRNA associated with clarithromycin resistance in Helicobacter pylori strains isolated from Korean patients. J Microbiol Biotechnol. 2008;18(9):1584-9. 
10. Abdollahi H, Savari M, Zahedi MJ, Moghadam SD, Hayatbakhsh Abasi M. Detection of A2142C, A2142G, and A2143G mutations in 23s rRNA gene conferring resistance to clarithromycin among Helicobacter pylori isolates in Kerman, Iran. Iran J Med Sci. 2011;36(2):104-10.

11. Binh TT, Shiota S, Suzuki R, Matsuda M, Trang TTH, Kwon DH, Iwatani S, Yamaoka Y. Discovery of novel mutations for clarithromycin resistance in Helicobacter pylori by using next-generation sequencing. J Antimicrob Chemother. 2014;69(7):1796-803.

12. De Francesco V, Giorgio F, Hassan C, Manes G, Vannella L, Panella C, lerard E, Zullo A, et al. J Gastrointestinal Liver Dis. 2010;19(4):409-14.

13. Wang D, Guo Q, Yuan Y, Gong Y. The antibiotic resistance of Helicobacter pylori to five antibiotics and influencing factors in an area of China with a high risk of gastric cancer. BMC Microbiol. 2019;19(1):152.

14. Megraud F, Coenen S, Versporten A, Kist M, Lopez-Brea M, Hirschl AM, Andersen LP, Goossens H, Glupczynski Y. Helicobacter pylori resistance to antibiotics in Europe and its relationship to antibiotic consumption. Gut. 2012;201(62):34-42

15. Wahab H, Khan T, Ahmad I, Jan A, Younas M, Shah H, AbdEl-Salam NM, Ayaz S, Ullah R, Wasim MA. Detection of H. pylori by PCR method using ureA and ureC gene in gastric biopsy sample. 2015;9(3):2165-74

16. Mégraud $F$, Lehours $P$. Helicobacter pylori detection and antimicrobial susceptibility testing. Clin Microbiol Rev. 2007;20(2):280-322.

17. Abd Al Rahem SA, Elhag WI. Molecular Detection of Helicobacter pylori in Drinking Water in Khartoum State (Sudan). Afr J Med ences. 2018;3(5).

18. Engstrand L, Nguyen A, Graham D, El-Zaatari F. Reverse transcription and polymerase chain reaction amplification of rRNA for detection of Helicobacter species. J Clin Microbiol. 1992;30(9):2295-301.

19. Furuta T, Soya Y, Sugimoto M, Shirai N, Nakamura A, Kodaira C, Nishino M, Okuda M, Okimoto T, Murakami K. Modified allele-specific primerpolymerase chain reaction method for analysis of susceptibility of Helicobacter pylori strains to clarithromycin. J Gastroenterol Hepatol. 2007; 22(11):1810-5

20. Hall TA. BioEdit: a user-friendly biological sequence alignment editor and analysis program for Windows 95/98/NT. In: Nucleic acids symposium series, vol. c1979-c2000. London: Information Retrieval Ltd; 1999. p. 95-8.

21. Shoosanglertwijit $R$, Kamrat N, Werawatganon D, Chatsuwan T, Chaithongrat S, Rerknimitr R. Real-world data of Helicobacter pylori prevalence, eradication regimens, and antibiotic resistance in Thailand, 2013-2018. JGH Open. 2020;4(1):49-53.

22. Shah $H$, Shah $P$, Jarag $M$, Shah $R$, Shah $P$, Naik K. Prevalence of Helicobacter pylori infection in gastric and duodenal lesions as diagnosed by endoscopic biopsy. Int J Med Sci Public Health. 2016;5(1):93-7.

23. Ghaith D, Elzahry M, Mostafa G, Mostafa S, Elsherif R, Ramzy I. Mutations affecting domain $V$ of the 235 rRNA gene in Helicobacter pylori from Cairo, Egypt. J Chemother. 2016;28(5):367-70.

24. Malfertheiner P, Megraud F, O'Morain CA, Atherton J, Axon AT, Bazzoli F, Gensini GF, Gisbert JP, Graham DY, Rokkas T. Management of Helicobacter pylori infection—-the Maastricht IV/Florence consensus report. Gut. 2012; 61(5):646-64.

25. Rahama ABM, Mohamed AE, Elgemaabia OM, Yassin ME, Enan KM, Ahmed WAE, Ahmed BSR. Molecular detection of helicobacter pylori among gastroduodenitis and peptic ulcer patients in khartoum state. J Biomed Pharma Res. 2014:3(5):41-4.

26. Mamoun M, Ek ME, Abdo A, Hassan M. Molecular identification of $16 \mathrm{~s}$ ribosomal RNA gene of Helicobacter pylori isolated from gastric biopsies in Sudan. Am J Microbiol Res. 2015;3(2):50-4.

27. Nishizawa T, Suzuki H. Mechanisms of Helicobacter pylori antibiotic resistance and molecular testing. Front Mol Biosci. 2014;1:19.

28. Tanih NF, Ndip RN. Molecular detection of antibiotic resistance in south African isolates of Helicobacter pylori. Gastroenterol Res Pract. 2013;2013:6.

29. Gerrits MM, van Vliet AH, Kuipers EJ, Kusters JG. Helicobacter pylori and antimicrobial resistance: molecular mechanisms and clinical implications. Lancet Infect Dis. 2006;6(11):699-709.

30. Jaka H, Rüttgerodt N, Bohne W, Mueller A, Gross U, Kasang C, Mshana SE. Helicobacter pylori mutations conferring resistance to Fluoroquinolones and clarithromycin among dyspeptic patients attending a tertiary hospital, Tanzania. Can J Gastroenterol Hepatol. 2019;2019:7.

31. Park JY, Dunbar KB, Mitui M, Arnold CA, Lam-Himlin DM, Valasek MA, Thung I, Okwara C, Coss E, Cryer B. Helicobacter pylori clarithromycin resistance and treatment failure are common in the USA. Dig Dis Sci. 2016;61(8):2373-80.
32. Imyanitov E, Buslov K, Suspitsin E, Kuligina ES, Belogubova E, Grigoriev MY Togo A, Hanson K. Improved reliability of allele-specific PCR. Biotechniques. 2002;33(3):484-90

33. Ha TMT, Le PTQ, Nguyen VN, Phan TN, Paglietti B. Helicobacter pylori $23 \mathrm{~S}$ rRNA gene mutations associated with clarithromycin resistance in chronic gastritis in Vietnam. J Infect Dev Countries. 2018;12(07):526-32.

34. Cheng C, Zhou Y, Yang C, Chen J, Wang J, Zhang J, Zhao G. Detection of rare point mutation via allele-specific amplification in emulsion PCR. BMB Rep. 2013;46(5):270.

35. Jung SW, Sugimoto M, Shiota S, Graham DY, Yamaoka Y. The intact dupA cluster is a more reliable Helicobacter pylori virulence marker than dupA alone. Infect Immun. 2012;80(1):381-7.

36. Khan R, Nahar S, Sultana J, Ahmad MM, Rahman M. T2182C mutation in 23S rRNA is associated with clarithromycin resistance in Helicobacter pylori isolates obtained in Bangladesh. Antimicrob Agents Chemother. 2004;48(9): 3567-9.

37. Fasciana T, Calà C, Bonura C, Di Carlo E, Matranga D, Scarpulla G, Manganaro M, Camilleri S, Giammanco A. Resistance to clarithromycin and genotypes in Helicobacter pylori strains isolated in Sicily. J Med Microbiol. 2015:64(11):1408-14.

\section{Publisher's Note}

Springer Nature remains neutral with regard to jurisdictional claims in published maps and institutional affiliations.
Ready to submit your research? Choose BMC and benefit from:

- fast, convenient online submission

- thorough peer review by experienced researchers in your field

- rapid publication on acceptance

- support for research data, including large and complex data types

- gold Open Access which fosters wider collaboration and increased citations

- maximum visibility for your research: over $100 \mathrm{M}$ website views per year

At BMC, research is always in progress.

Learn more biomedcentral.com/submissions 